\title{
The Separation of Property and Control and its Costs a Century Old Problem that Seems Modern
}

\author{
JOSÉ G. VARGAS-HERNÁNDEZ ${ }^{* *}$ and YOESLANDY GARCÍA MARSILIO²
}

${ }^{1}$ Centro Universitario de Ciencias Económico Administrativas, Universidad de Guadalajara Periférico Norte 799 Edif. G201-7,, Núcleo universitario Los Belenes, Zapopan, 45100 Jalisco México. 'Licenciado en Contabilidad y Finanzas Centro Universitario de Ciencias Económico Administrativas, Universidad de Guadalajara Estudiante de Maestría en Negocios y Estudios Económicos Prolongación Mariano Bárcenas № 435 Entre González Ortega y Paloma, No. Int. 26. Hogares del Batán Zapopan, C.P. 45190 Jalisco México.

\begin{abstract}
The Agency Costs resulting from the conflict between principals and agents, due to the separation of ownership and control in the capitalist enterprise, was analyzed in many works of the last century. Could we assume that the current globalization of companies has increased the differences between principals and agents? Does this scenario lead to an increase in Agency Costs in those companies with the greatest presence in the global economy? The objective of this article is to compile studies that will allow us to answer these questions affirmatively and conclude that large transnational, multinational or global companies involve higher Agency Costs than those that remain within national borders.
\end{abstract}

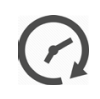

\section{Article History}

Received: 06 August 2018 Accepted: 26 September 2018

\section{Keywords}

Agency, Agents; Control; Costs; Monitoring; Principals.

\section{Introduction}

Although the twentieth century has gone down in history because of the great scientific discoveries, the two World Wars, the emergence and development of large companies and industries that spread throughout the world with the impetus of globalization, among other important events that carried out during those 100 years. Also all this contributed to the emergence of the problem that is addressed in the present work and that has to do explicitly with the separation of ownership and control in large companies and the conflicts that this generates.

Until the nineteenth century, both ownership and control were concentrated in the figure of the capitalist or entrepreneur, absolute owner of the means of production. But this situation was evolving as companies grew and the so-called dispersion

CONTACT José G. Vargas-Hernández $\$ josevargas @ cucea.udg.mx 9 Centro Universitario de Ciencias Económico Administrativas, Universidad de Guadalajara Periférico Norte 799 Edif. G201-7,, Núcleo universitario Los Belenes, Zapopan, 45100 Jalisco México. (c) (i)

(C) 2018 The Author(s). Published by Enviro Research Publishers.

This is an 2 Open Access article licensed under a Creative Commons license: Attribution 4.0 International (CC-BY).

Doi: http://dx.doi.org/10.12944/JBSFM.01.01.02 
of capital in shares and capital markets, which are nothing but a way and a space where the owner of capital can exchange his ownership in shares, partially or totally by liquid capital and reinvest this either in the company or in another business.

In this way companies ceased to be the absolute property of a person to become the property of several individuals, limiting the performance of the will of each of them. This caused that the capitalist as owner and director of the company, could be freed of the executive functions and devote to enjoy the benefits of the business, leaving his position to a General Manager capable of making the decisions, managing and representing the interests of all owners.

This phenomenon began to attract the attention of experts and researchers in the early thirties by the magnitude that was gaining. Thus, studies like those of Berle and Means ${ }^{1}$ were published, where they addressed the situation of shared capital among several share holders in large companies, which made them owners of a smaller or greater part of it, but limited them in terms of decision making. It took shape what we know today as the Theory of the Agency, in which the authors identified different interests between principals (owners, shareholders) and agents (managers, administrators).

Almost a century has passed since the emergence of this separation, but far from being solved differences have increased, product of the excessive growth of companies and internationalization, which has forced even the most capable and conservative to put control of their signatures in the hands of others, given the impossibility of being everywhere, knowing about everything, or what is the same, having information asymmetries that for Fama and Jensen, ${ }^{2}$ are the main reason why problems of the agency persist.

As a result of the lack of confidence on the part of principals towards managers, due to the rationality of the latter, which could lead them to act opportunistically. ${ }^{3}$ The agency costs increase and the clear establishment of rules and procedures for decision-making along with external controls that minimize the conflict of interest between shareholders and administrators. ${ }^{4}$

\section{Background of the Problem}

The challenges of globalization have led millions of companies to embark on the conquest of international markets, turning them into large multinationals and transnationals with a presence in most markets and a major role in global finance. But before this event took unimaginable magnitudes and many authors were concerned and occupied the gap that opened between ownership and control or between principals and agents.

Berle and Means. ${ }^{1}$ In their book The Modern Corporation and Private Property, took on the task of identifying the problems caused by the separation of ownership and control, becoming pioneers in this research topic. In their study they warn about the concentration of economic power caused by the increase of the big corporation and the emergence of a powerful class of professional managers, isolated from the pressure not only of the shareholders, but also of the general public.

They conclude that the structure of corporate law in the United States in the 1930s reinforced the separation of ownership and control and that there was no longer any certainty that in a corporation essentially the interests of the shareholders were executed, since the managers had sufficient independence to pursue their own interests, even if they were partially opposed to those of the shareholders. This study was framed in North American companies and constituted a mandatory reference on the subject until the seventies.

Jensen and Meckling. ${ }^{5}$ In their study entitled Theory of the Firm: Management Behavior, Agency Costs and Ownership Structure, address the conflict of interests between principals and agents, from the perspective that many owners of firms in the market, deliver voluntarily their companies under the tutelage of an administrator, establishing complex contractual relationships between them that limit the actions of both parties. The levels of these relationships depended on the legal and regulatory framework and the determination of restrictive clauses that committed the agent to perform services for the benefit of the principal. The principal delegated to the agents' decisions that granted them some authority. All this resulted in an increase in agency costs. 
The authors acknowledge that both principals and agents are utility maximizers and will look after their own interests, so the principal will establish incentives to align the interests of the agent, and will incur monitoring costs. Likewise, the agent will use resources to signal the principal acting according to his interests. So, as long as there are divergences between principals and agents, there will be no possible way to find zero costs by aligning the interests of the agent with those of the principal. This study has some limitations that basically start from the assumptions that are assumed, where it can be found that: There is no tax, that external shareholders do not have the right to vote, that the owner's wages and the size of the firm are fixed and that it is not possible to carry out monitoring or guarantee activities.

Another study that deals with the issue of the agency with great depth is that of Fama and Jensen. ${ }^{2}$ Titled, Separation of property and control, where they explain that the survival of certain organizations is characterized by the separation of ownership and control and that this problem can occur both in large organizations and in much smaller ones. They agree with other authors that the agency's problems persist thanks to information asymmetries between principals and agents. In addition, they affirm that organizations are based on the relationship that is established through contracts and that they are divided into written and not written. These are signed between the owners of the factors of production and customers, thus establishing the "rules of the game" or the rights of each agent in the organization.

For them, problems in organizations are aggravated when the process of making important decisions rests with the administrators, who are not precisely the residual claimants or owners of the company and, therefore, do not have a significant share of the wealth generated or not your decisions. This causes an increase in the agency's costs, due to the structuring and monitoring of contracts between agents with conflicting interests. For agency problems to manifest, according to Arrow. ${ }^{6}$ In his study The economics of agency, it is necessary that there are situations of asymmetric information, under two fundamental assumptions that he describes as: First, that he finds hidden information or adverse selection. One of the parties knows something that the other ignores, and second, that there are hidden actions or moral hazard. One of the parties carries out actions in order to maximize its usefulness to the detriment of the other party.

Authors such as Gedajlovic and Shapiro, ${ }^{7}$ published the article entitled Management and ownership effects: evidence from five countries, where they recognize two situations related to ownership and control that can create agency costs: The first, when executives commit themselves short-term high-cost activities, designed to obtain extra remuneration, other than salary that reduce corporate profitability and increase costs, and the second, occurs if managers seek to satisfy their needs for power, prestige and status through of long-term strategic decisions that increase the size of the company but not its corporate results.

\section{Theoretical - Conceptual Review}

Agency costs are those that are generated because of information asymmetries between principals and agents when there is a separation between ownership and control. These costs are derived from monitoring contracts and controlling the behavior of agents by the principals. While agents involve costs to send signals that they are worthy of the principal's trust. $^{8}$

According to the strategic approach, the internationalization of companies is the result of the adoption of a series of strategies in which both the resources and capabilities of the company and the opportunities and threats of the environment are considered. The internationalization of companies is the process by which a company participates in the reality of globalization, that is, the way in which the company projects its activities totally or partially, to an international environment and generates commercial, financial or of knowledge between different countries. ${ }^{9}$

It should be clear that the separation of ownership and control is an inherent problem in firms that operate both internally and outside of a country, but for the purposes of this paper the behavior of the problem will be analyzed in those that go beyond national borders. It is prudent to clarify that 
there are several classifications for these firms that begin to have a presence in different countries and markets.

Although there are discrepancies among the authors regarding the following types, for the Understanding of the present work will be established as follows:

\section{International Companies}

Are those that export or import goods. They do not have a relevant presence in the destination country and are not interested in adapting their products to the needs of the country that receives them. Rather, it takes advantage of cultural distance.

\section{Multinational Companies}

Are those with a global focus in terms of markets, have presence in 2 or more countries and not only export, but also perform productive activities in those countries. They follow strategic plans of domain of markets that are made and directed in a centralized manner and tend not to accept local investors.

\section{Transnational Corporations}

Those that have a presence in many countries where they usually establish subsidiaries or franchises that do not have the same legal personality as the parent company, usually located in the country of origin. This type of companies can accept investors from all countries where they are present.

\section{Global Companies}

Are those with the capacity to act in any country in the world because they see the planet as a single market. They can have a unique headquarters from where all the strategies start in a general way, but then each country adapts the products or services according to the culture, language, idiosyncrasies and needs of local consumers.

The concepts or characteristics of these companies have an important relationship with this work because, due to the magnitude and cost of the operations they carry out, the diversity of scenarios where they have presence and the high levels of uncertainty and risk with which they work make them firm representatives of the separation of ownership and control and the unlimited increase of agency costs.
At present, many companies follow business initiatives that lead them to compete outside their borders. For Peng. ${ }^{10}$ This behavior is defined as the combination of proactive innovation and the search for risks that run when overcoming national borders in order to generate value for the organization. All this can be achieved in three fundamental ways according to the author: Through direct Exports, by the establishment of franchises or licenses and by direct foreign investment, understand (alliances, wholly-owned subsidiaries and / or foreign acquisitions).

The international presence in one or several countries invariably leads to an increase in agency costs that could be divided into four fundamental concepts according to Arruñada. ${ }^{11}$

\section{Costs of Formalization}

Design and drafting of contracts in which the obligations of the parties are detailed.

\section{Supervision Costs}

Incurred by the principal for the selection of the right person before the signing of the contract and after the signature of the latter, to control the activity of the agent.

\section{Guarantee Costs}

Subscribed by the agent to guarantee the principal that he will not carry out harmful actions for him.

\section{Residual Loss}

It is in which the principal incurs by the decisions adopted by the agent and that deviate from those agreed in the contract.

\section{Review of the Empirical Literature}

Although the current studies have not sufficiently explored the influence that could have for the agency costs that the companies grow towards international markets, the intuition about the phenomenon of business globalization has led some authors to establish empirical the existing relationship between agency costs and internationalized companies. An investigation by Lee and Kwok. ${ }^{12}$ Helps to begin to understand the relationship mentioned above. Its study is based on a comparison between multinational companies and domestic companies 
regarding the influence of some international environmental factors on the capital structure. The costs of agency and bankruptcy costs were taken as determining factors of the capital structure.

One of the most important findings of this research argues that, due to the complexity of international operations, agency costs tend to increase with respect to companies that operate in domestic markets because of surveillance and linking activities of multinationals. These activities are mainly audit and preparation of multiple financial statements for each country in which the company has operations. As the subsidiaries of multinationals are located in different countries, with different national accounting standards it is more difficult and more difficult to prepare consolidated financial statements. Alternatively, geographic dispersion also substantially increases audit costs.

Mention may also be made of the research work carried out by Martínez and Tejerina. ${ }^{13}$ on International Acquisitions and Control in Spanish Industrial Companies, where, although the topic of analysis of this work is not addressed directly, if it is explained how it works from the point of view of the acquisitions of companies, which we have already identified as a way to internationalize the firm. For them, acquisitions are ways to execute foreign direct investments, which causes the growth of firms and limits managers to establish optimal control systems and to obtain relevant and necessary information, which minimizes delegating decision rights in individuals more prepared and better informed about the new environment. This inevitably results in increased agency costs. The results of this work were based on a sample of 298 acquisitions of Spanish industrial companies between 1991 and 1994.

In the study conducted by Fortuna. ${ }^{14}$ it states that in the case of large corporations there is a double agency relationship as a result of the transfer of powers of the shareholders to the Board of Directors and from this to the senior management. In addition, he affirms, based on the theories of the management school, that the mismatch of interests between internal and external shareholders, the difficulty of oversight and the large size of the corporation increase the agency problem and result in the management going to have an incentive towards opportunistic behavior, pursuing the satisfaction of their own objectives, which will mean a deviation from the financial objective of the company, to the detriment of the vast majority of shareholders (the external).

Works such as Chang and Taylor. ${ }^{15}$ analyze how in complex organizations of multiple business units, the manager of a large corporation can be seen as the principal since it is the manager in charge of watching over the interest and the correct functioning of the company, an organization as a whole, while the managers of several subunits held by the corporation identify themselves as agents. This is known as an extended agency relationship, where the managers of the subunits can try to maximize their own interest and the interest of their subunits, even though this may have a negative implication for the corporation. It is evident how the geographical, cultural and national adaptation between the headquarters and its foreign subsidiaries can increase the uncertainty of the corporation about the decisions taken by its subsidiaries and increase agency costs.

Authors such as Egelhoff. ${ }^{16}$; Baliga and Jaegar. ${ }^{17}$ and the own Chang and Taylor..$^{15}$ defend the criterion in their work of being able to monitor the subsidiaries through the control of personnel, that is, through the appointment of managers or directors who come from the country in which the headquarters is located (the expatriates). This is consistent with the concept of behavior control, where it is expected that expatriate managers and directors are more likely to act in the interests of headquarters than foreign managers. But information asymmetries could act negatively in these cases and the possibility of opportunism by national managers would continue to be present, as well as the country's limitations regarding the employment of foreign personnel to the detriment of nationals and the costs of agency.

In research such as that of Wright, Madura, and Wiant. ${ }^{18}$ an analysis is performed using data from the capital market to empirically examine the theory that multinational companies with greater exposure to foreign markets incur higher agency costs than the multinationals less exposed and then the domestic corporations. For this, they use an event study methodology to measure the abnormal returns associated with four separate events: (1) debt offers; 
(2) share offers; (3) organizational restructuring; and (4) takeover defenses. The results of the four events studies and their associated cross sections allow you to validate the main hypothesis that multinational firms with greater presence in foreign markets experience higher agency costs than multinational companies or less exposed domestic corporations.

It is also pertinent to compile in this article the results of the study conducted by Doukas and Pantzalis. ${ }^{19}$ Where, among other issues, the effect of debt agency costs on the leveraging of 6951 multinationals and US nationals is discussed, during the period between 1988 and 1994. This paper concludes that there is a negative effect of debt agency costs on long-term leverage, being significantly higher for multinational companies than non-multinationals, which indicates that this type of companies they are subject to higher debt agency costs than companies without operations abroad. This is consistent with the view that multinational corporations are prone to higher agency costs than domestic companies because their greater geographic diversity causes difficulties in gathering and processing information, in addition to making monitoring more expensive than of national companies.

Therefore, it is expected that the inherent agency problem between the shareholders and the bondholders will be aggravated by the geographical distances of the multinationals and, therefore, the bondholders will require higher interest payments on loans to companies that they are more susceptible to information asymmetries and higher supervision costs.

Another study by Mustapha. ${ }^{20}$ Conducted in Malaysia, which analyzed the behavior of monitoring costs in 235 multinational firms, using as a reference the levels of supervision implemented by these companies, mainly taking internal and external audits as study components; It showed that companies with multinational status have significantly more external audit costs. This result coincides with previous studies and can be explained by the need for an independent insurance system to control the operations of foreign subsidiaries in the multinational environment and proving that external auditors are seen as more independent than internal auditors.
The results validate the thesis of the increase in agency costs in multinational companies, since we understand that the costs of monitoring are in themselves agency costs.

\section{Research Method}

For the development of this research on the costs of agency in international companies, a descriptive and explanatory study was carried out, since the concepts related to this topic are described, as well as a review on the emergence of the agency theory and to compile different empirical investigations that explain the influence and behavior of this type of costs, when the companies transcend their national borders and expand towards foreign markets.

\section{Analysis of Results}

All the studies reviewed in this article show similar results, despite having been applied in different countries, geographical areas and types of companies. All authors agree in some way that there is a close relationship between the growth of companies outside their borders and the agency costs they incur. In that as they are expanding and locating in different countries and markets, the conflicts between principals and agents increase, making it more and more difficult to supervise and monitor the behavior of managers or administrators.

Negative effects of debt agency costs on long-term leverage are also observed, being significantly higher for multinational companies than for national ones. This effect of debt agency costs on leverage increases with the degree of participation of companies in foreign markets.

\section{Conclusions}

The information gathered in this article allows to know a little more about the emergence and development of the theory of the agency, as a result of the separation of ownership and control, a gap that tends to increase when companies grow and internationalize. It also reflects the upward behavior of agency costs in these companies under analysis. This increase in the costs of agency in companies that transcend many borders, it can affirm that it occurs due to the geographical distance that causes difficulties to gather and process the information, in addition to being able to monitor the behavior of the 
agents through internal audits as well as externally. It is more expensive and there is also a gradual increase in the uncertainty of corporations about the decisions taken by their subsidiaries in the rest of the world.

If all the results of the studies gathered in this study are interrelated, it is possible to affirm that as domestic companies move their operations to more foreign markets, agency costs gradually increase, So, if taken the concepts as reference of companies mentioned in this paper, global companies will incur in higher costs than multinationals and transnationals and these are higher costs than international ones. And each one of them will have higher agency costs than those of domestic companies.

\section{Acknowledgement}

This research received no specific grant from any funding agency in the public, commercial, or notfor-profit sectors.

\section{Conflict of Interest}

There is no conflict of interest

\section{References}

1. Berle, A. y Means, G. (1962). The Modern Corporation and Private Property. Nueva York, Estados Unidos: MacMillan.

2. Fama, E. y Jensen, M. (1983). Separation of ownership and control. Journal of Law and Economics, 26(2), 301-325.

3. Barney, J. B. y Ouchi, W. G. (1986). Organizational Economics. San Francisco, Estados Unidos: Jossey-Bass.

4. Baysinger, B. y Hoskisson, R.E. (1990): "The composition of boards of directors and strategic control: Effects on corporate strategy". Academy of Management Review, 15(1), 72-87.

5. Jensen, M. y Meckling, W. (1976). Theory of the firm: Managerial behavior, agency cost and ownership structure. Journal of Law and Economics, 3(4), 305-360.

6. Arrow, K.J. (1991). The economics of agency. En Pratt, J.W. y Zeckhauser, R.J. (eds.)

7. Gedajlovic, E.y. Shapiro, D. (1998). Management and ownership effects: evidence from five countries. Strategic Management Journal, 19(6), 533-555.

8. Peng, M. W. (2010). Chapter 11: Goberning the corporation around the world. Global Strategy (pp. 210-245). CENGAGE Learning.

9. Araya, A.(2009). ElProceso de Internacionalización de Empresas. Revista digital Escuela de Administración de Empresas, 3(3) 18-25.

10. Peng, M.W. (2012). Global Strategy. Cincinnati, Estados Unidos: Thomson South-Western.

11. Arruñada, B. (1990). Economía de la empresa: un enfoque contractual. Barcelona,
España: Ariel.

12. Lee, K.C. y Kwok, C.C.Y. (1988). Multinational Corporations vs Domestic Corporations: International Environmental Factors. Journal of International Business Studies, 19(2), 195-217.

13. Martínez A. y Tejerilla F. (1999). Adquisiciones Internacionales y Control en las Empresas Industriales Españolas. Revista Cambio Tecnológico y Competitividad, 781, 130-131.

14. Fortuna J. M. (1999). Discrecionalidad directiva, costes de agencia y mecanismos de control en las ofertas públicas de adquisición de acciones en España. Tesis Doctoral. Documentary Repository. Universidad de Valladolid. España.

15. Chang, E. y Taylor, M.S. (1999). Control in multinational corporations (MNCs): The case of Korean manufacturing subsidiaries. Journal of Management, 25(4), 541-565.

16. Egelhoff, W. G. (1984). Pattern of control in US, UK and European multinational corporations. Journal of International Business Studies, 15(2), 73-83.

17. Baliga, B. R. y Jaeger, A. M. (1984). Multinational corporations: Control systems and delegation issues. Journal of International Business Studies, 15(2), 25-40.

18. Wright, F. W., Madura, J. y Wiant, K. J (2002). The differential effects of agency costs on multinational corporations: Theory and evidence. Applied Financial Economics, 12(5), 347-359.

19. Doukas, J. A. y Pantzalis, Ch. (2003). 
Geographic diversification and agency costs of debt of multinational firms. Journal of Corporate Finance 9, 59 - 92.

20. Mustapha, M. (2011). Monitoring costs of MNC: an agency theory perspective. In:
International Conference of Global Academy of Business and Economic Research, 2223 Dis 2011, Dubai, U.A.E. (pp. 118-133). (Unpublished). 